\title{
The Impact of Syrian Immigrant Patients on Health Service Delivery: The Case of Istanbul
}

\section{Suriyeli Göçmen Hastaların Sağlık Hizmeti Sunumuna Etkisi: İstanbul Örneği}

Cite as: Sevim E, Nal, M. The impact of Syrian immigrant patients on health service delivery: The case of Istanbul. Journal of Health and Nursing Management. $2021 ; 8(3): 314-320$.

\begin{abstract}
Aim: The study investigates service delivery impacts to Syrian patients on the Turkish health care system.

Method: The study was carried out in a retrospective and used the cross-sectional descriptive design using the data of Syrian patients served in public and private health institutions throughout Istanbul in 2018.

Results: Healthcare services were provided to 1,419,069 Syrian patients in health institutions in Istanbul in 2018. This number constitutes $1.43 \%$ of general patient admissions. While the ratio of Syrian patients to outpatient clinic admissions was $1.05 \%$, the rate for emergency services admissions was $2.82 \%$. In addition, the rate of Syrian patients in general admissions was $1.43 \%$, while the rate among inpatients was $6.10 \%$.

Conclusion: Turkey, despite having a health workforce and technical possibilities (numbers of hospital beds, MR and CT devices) to have less opportunities from OECD countries, which also share these resources with Syrian patients. Turkey offers health services to a substantial amount of Syrian patients. Immigrant Syrian patients constitute $1.43 \%$ of general admissions to hospitals. It is thought that this small health service burden will not adversely affect the delivery of health services.
\end{abstract}

Keywords: Health system, service delivery, Syrian patients, international migration.

\section{Öz}

Amaç: Çalışmanın amacı, Suriyeli hastalara hizmet sunumunun Türkiye sağlık sistemi üzerindeki etkilerini incelemektir.

Yöntem: Çalışma, 2018 yılı içerisinde İstanbul ili genelinde kamu ve özel sağlık kuruluşlarında hizmet verilen Suriyeli hasta verileri kullanılarak retrospektif ve kesitsel olarak tanımlayıcı tasarımda gerçekleştirilmiştir.

Bulgular: İstanbul'da bulunan sağlık kuruluşlarında 2018 yılı içerisinde toplam 1.419.069 Suriyeli hastaya sağlık hizmeti verilmiştir. Bu sayı genel hasta başvurularının \%1,43'ünü oluşturmaktadır. Suriyeli hastaların poliklinik başvuruları içerisindeki oran \%1,05 olurken, acil servis başvuruları içerisindeki oran \%2,82 olarak gerçekleşmiştir. Ayrıca Suriyeli hastaların genel başvurular içerisindeki oranı \%1,43 iken yatarak tedavi olan hastalar içerisindeki oranı $\% 6,10$ olarak gerçekleşmiştir.

Sonuç: Türkiye, sahip olduğu sağlık insan gücü ve teknik olanaklar (hastane yatağı, MR ve BT cihazı sayıları) açısından OECD ülkelerinden daha düşük olanaklara sahip olmasına karşın, bu kaynağı Suriyeli hastalarla da paylaşmaktadır. Türkiye çok sayıda Suriyeli hastaya sağlık hizmeti sunmaktadır. Ancak bu durumun sağlık sistemi üzerinde hizmet sunumu açısından önemli bir olumsuz etkisinin olmadığı sonucuna ulaşılmıştır.

Anahtar Sözcükler: Sağlık sistemi, hizmet sunumu, Suriyeli hastalar, uluslararası göç.
Recieved / Geliş: 30.03.2021

Accepted / Kabul: 25.08.2021

Published Online / Online Yayın: 25.12.2021

Corresponding author / Sorumlu yazar: Ekrem Sevim

Bandırma Onyedi Eylül University,

Faculty of Health Sciences,

Department of Health Management, Balıkesir, Turkey.

esevim@bandirma.edu.tr

ORCID: 0000-0003-0697-5899

M. Nal 0000-0002-3282-1124 Kütahya Health Sciences University, Faculty of Health Sciences, Department of Health Management, Kutahya, Turkey. 


\section{Syrian patients' impacts on the healthcare system}

Suriyeli hastaların sağlık sistemi üzerindeki etkileri

\section{Introduction}

The main goal of health systems is to provide health services to the whole society; is delivered in an effective, efficient and equitable manner (Ministry of Health [MoH], 2012). This goal can be achieved with a well-structured structuring, financing and service provision (Uğurluoğlu \& Çelik, 2005). Today, health systems are increasingly challenged to meet the needs of an increasing number of patients due to increasing population, chronic diseases and even epidemics (Hopfe, Prodinger, Bickenbach \& Stucki, 2018). In 2011, after the internal turmoil emerged in Syria Syrians coming to Turkey; In addition to the needs such as education and accommodation, it also needs health services. In this context Turkey under the umbrella of the health system; A number of Syrian refugees have entered the population of countries such as Croatia, Ireland, Norway, Finland and Denmark (United Nations [UN], 2019). Also during this period, the number of irregular migrants from various countries outside Syria and emigrated to Turkey in excess of 5.5 million (Senturk, 2020). Turkey healthcare system approximately 83 million (Turkey Statistics Institute [TurkStat], 2020) as well as its population, 3.5 million Syrian immigrants "temporary asylum" to keep under the scope of the status and health services offers (Ministry of Interior [MOI], 2019).

Korkmaz (2014) analyzed the applications of Syrian immigrants to Kilis State Hospital between 2012 and 2014 and found that Syrian immigrants increased the workload of health workers. Turkey's healthcare system is at risk due to irregular migration. Migration has significant negative effects on the health systems of the country, especially in terms of various public health problems, in terms of both migrants' and local people's access to services (ilhan, Gözlü, Atasever, Dündar, Büyükgök \& Barkan, 2016). Syrians living in Turkey, according to the province's spread is different compared to the population of the provinces, also affect access to health care and service delivery capacity (Önder, 2019).

This research, "Does Syrian immigrants harm the provision of health services in Istanbul?" seeking an answer to the question. This study is considered important because it is the first study to reveal whether Syrian immigrants harm the provision of health services in Istanbul, Turkey's largest city.

\section{Method}

Aim and Type of the Research: The aim of the study is investigating the impacts of service delivery to Syrian patients on the Turkey health care system. The study was carried out in a retrospective and cross-sectional descriptive design.

Research Place and Features: The study was conducted by using data from the Istanbul Provincial Health Directorate to cover the patients who were served in 2018 throughout the province of Istanbul.

Study Population and Sample: Within the scope of the study, the data of patients served in public and private health institutions throughout Istanbul province in 2018 were examined.

Data Collection: The data required within the scope of the research were obtained from the Istanbul Provincial Health Directorate after the permission of the institution.

Data Analysis: Microsoft Excel and SPSS 25 package programs were used for the analysis.

Ethical Aspect of the Research: For the study, official permission was obtained from the institution that provided the data with the ethics committee approval of the relevant university dated 03.07.2020 and numbered 2020-29.

Limitations of the Study: The study is limited to the records of patients who received service in the province of Istanbul in 2018 and reported to the Istanbul Provincial Health Directorate, and cases that were not notified are excluded. 


\section{Syrian patients' impacts on the healthcare system}

Suriyeli hastaların sağlık sistemi üzerindeki etkileri

\section{Results}

As a result of the analysis of the obtained data, Syrian patients who benefit from health services; The ratio of applications to public or private hospitals, outpatient clinics, emergency services and inpatient services were analyzed.

Table 1. General patient admission numbers

\begin{tabular}{lcc} 
Admission Type & Admission Numbers & Admission Rates (\%) \\
\hline Citizens of the Republic of Turkey Patient Applications & $86,805,421$ & 98.39 \\
Syrian Patient Applications & $1,419,069$ & 1.61 \\
Total & $\mathbf{8 8 , 2 2 4 , 4 9 0}$ & 100 \\
\hline
\end{tabular}

When the applications made to health institutions according to patient types are examined, the total number of applications was 88.224.490. Besides the citizens of the Republic of Turkey, it is observed that the application 1,419,069 made by the Syrian nationals. Proportionally, this number constitutes $1.61 \%$ of all applications (Table 1 ).

Table 2. Number of admission of Syrian patients by type of hospital

\begin{tabular}{lccccc} 
Hospital Type & $\begin{array}{c}\text { Number of } \\
\text { Hospitals }\end{array}$ & $\begin{array}{c}\text { Number of } \\
\text { Admission }\end{array}$ & Average & $\mathbf{t}$ & $\mathbf{p}$ \\
\hline Public Hospital & 73 & $1,348,449$ & $18,471.90$ & 24.466 & 0.000 \\
Private hospital & 168 & 70,620 & 420.35 & & \\
\hline
\end{tabular}

Independent Sample T-Test was conducted to determine whether there is a significant difference between the admissions of Syrian patients to public and private hospitals according to the type of hospital. As a result of the test, it was determined that the number of applications of Syrian patients to public hospitals ( $n=1,348,449)$ was higher than the number of applications to private hospitals $(n=70.620)$, and this difference between them was statistically significant $(p<0.05)($ Table 2).

Table 3. Distribution of patients by departments where they receive service

\begin{tabular}{lccc} 
Hospital Admission & $\begin{array}{c}\text { General Patient } \\
\text { Admission }\end{array}$ & $\begin{array}{c}\text { Syrian Patient } \\
\text { Admission }\end{array}$ & $\begin{array}{c}\text { Syrian Patient } \\
\text { Admission Rate (\%) }\end{array}$ \\
\hline Number of Outpatient Admission & $69,518,547$ & 816,963 & 1.05 \\
Number of Emergency Service Admission & $19,162,101$ & 602,105 & 2.82 \\
Total Number of Admission & $88,678,449$ & $1,419,069$ & 1.43 \\
Number of Inpatients & $3,044,531$ & 185,819 & 6.10 \\
Number of Operations* & $2,186,170$ & 23,942 & 1.10 \\
\hline
\end{tabular}

${ }^{*}$ Number of Operations: Total of A, B, C, D, E and outpatient operations

Considering the distribution of patients according to the departments they receive service from, the rates of Syrian patient applications in general hospital applications are; It was $1.05 \%$ in outpatient clinic admissions, $2.82 \%$ in emergency room admissions, $1.43 \%$ in total outpatient and emergency room admissions, $6.10 \%$ in inpatients and $1.10 \%$ in the number of patients undergoing surgery (Table 3 ).

Table 4. Proportions of inpatients in hospital admissions

\begin{tabular}{lcc} 
Hospital Admissions and Rates & $\begin{array}{c}\text { General Patient } \\
\text { Admissions }\end{array}$ & Syrian Patient Admission \\
\hline Total (Outpatient and Emergency Service) Number of Admission & $88,680,648$ & $1,419,069$ \\
Total Number of Inpatients & $3,044,531$ & 185,819 \\
Hospitalization Rate by Number of Admission & $\% 3.43$ & $\% 13.09$ \\
\hline
\end{tabular}

When the rates of inpatients in hospital admissions were examined, the rate of inpatient treatment among all patients was $3.43 \%$, while this rate was $13.09 \%$ for Syrian patients (Table 4 ). 


\section{Syrian patients' impacts on the healthcare system}

Suriyeli hastaların sağılı sistemi üzerindeki etkileri

Table 5. Undergoing Surgery Rates ${ }^{*}$

Operation Type

Number of Transactions

Annual Operations Per Physician

Number of Non-Syrian Patients Undergoing Surgery

$2,162,228$

321.30

Number of Syrian Patients Undergoing Surgery

23,942

3.56

${ }^{*}$ Number of surgical clinicians: 9,730

When the effect of Syrian patients on operating room services is examined, it is seen that 2,162,228 surgical procedures are performed annually, excluding Syrian patients. In this case, it is seen that 321.30 procedures are performed per surgeon annually. On the other hand, 23,942 surgical procedures were performed on Syrian patients, with an annual increase of 3.56 procedures per surgeon (Table 5).

Table 6. Hospitalized Rates *

Operation Type

Number of Transactions

Annual Number of Patients Per Physician

Number of Non-Syrian Patients Hospitalized

$2,858,712$

159.67

Number of Syrian Patients Hospitalized

185,819

10.38

* Number of clinician specialists: 17,904

When the effects of Syrian patients on inpatient treatment services are analyzed, it is seen that, except for Syrian patients, $2,858,712$ inpatients are treated annually. It is observed that there are 159.67 inpatients per year per clinician specialist. On the other hand, 185,819 inpatients were applied to Syrian patients, and it was observed that 10.38 inpatient treatments were applied annually per clinician (Table 6).

Table 7. Number of health manpower, hospital beds and medical devices

\begin{tabular}{|c|c|c|}
\hline & Turkey & OECD Average \\
\hline Number of Physicians* & 1.88 & 3.59 \\
\hline Number of Nurses* & 2.34 & 10.58 \\
\hline Number of Dentists* & 0.74 & 0.38 \\
\hline Number of Hospital Beds* & 2.90 & 4.50 \\
\hline Number of MR Devices** & 11.20 & 16.70 \\
\hline Number of BT Devices ${ }^{\star *}$ & 14.90 & 26.60 \\
\hline
\end{tabular}

* Per thousand people

** Per one million people

Source: OECD, (2020), Health Statistics. https://www.oecd.org/health/health-statistics.htm

In the examination conducted in terms of health workforce, the average number of physicians per thousand people in OECD countries is 3.59 , the number of nurses is 10.58 and the number of dentists is 0.74 . Turkey in the same order for these ratios, 1.88 , and 2.34 and 0.38 . While the average number of hospital beds per every thousand population in OECD countries 4.50, this ratio was 2.90 in Turkey. In the examination made in terms of the number of medical devices, the average number of MRI devices per million people in OECD countries is 16.70 and the number of CT devices is 26.60 . these rates in Turkey are 11.20 and 14.90 (Table 7).

\section{Discussion}

Syrian migrants in Turkey, in terms of provision of health services, there are some possible potential impact on the country's health system. One of the areas where these effects can be seen the most is the provision of health services. When the findings obtained from the data discussed in the study are examined, it can be said that although a significant number of Syrian patients are provided with health services, this situation does not occupy a large place in service provision proportionally. It is seen that the rate of Syrian patients among all patients is $1.61 \%$. In the examination in terms of surgical procedures, the number of procedures per surgeon per year was 321.30 , while this number increased by 3.56 with the addition of Syrian patients. Likewise, in the examination of inpatient treatment services, it was observed that the number of inpatients per clinician specialist physician was 159.67 per year, while this number increased by 10.38 with Syrian patients. Even though it is thought that the majority of this burden increase is reflected in public hospitals, a significant increase cannot be mentioned. 


\section{Syrian patients' impacts on the healthcare system}

Suriyeli hastaların sağlık sistemi üzerindeki etkileri

When the hospital applications made are examined, it is seen that public hospitals respond to a significant part of the applications compared to private hospitals. It can be said that this situation is related to the fact that Syrian refugees can receive free treatment services in public hospitals and that they can benefit from the services provided free of charge from private institutions only in case of emergency or if they apply from public hospitals. In a study performed by Önder (2019) on health policy for Syrians living in Turkey, it was stated that policies that facilitate access to Syrian health services were implemented. Among these facilities, public hospitals and general emergency services are offered free of charge. Similarly, in the study conducted, the rate of Syrian patients in polyclinic services was $1.05 \%$, while the rate within emergency services was $2.82 \%$.

In a study conducted by Önal \& Keklik (2016) with 276 immigrants, it was revealed that immigrants experience various problems in accessing health services. Among the most important problems; employees' attitudes, communication, functioning of services and financial impossibilities are listed. Aslan, Sümbül \& Güzel (2018) stated that language and cultural differences have negative effects on the use of health services. In a study conducted by Tuzcu \& Ilgaz (2015) it was stated that the language problems experienced by immigrants affect the use of health services as well as getting the right diagnosis and treatment. In the study by Korkmaz (2016) poor living conditions are an issue that increases the health care needs of immigrants. In a study conducted by Gürbüz \& Duğan (2017) it was stated that Syrian immigrants could not benefit from health services adequately due to their language deficiency and they used interpreters when they could. It can be said that this situation negatively affects the use of health services. More than 3,400 translators were employed within the scope of the "Health Project" carried out by the Ministry of Health (2021) in cooperation with the European Union in order to facilitate the communication of Syrian patients with healthcare professionals and to facilitate the provision of healthcare services. Considering the high number of emergency room admissions and such problems, it can be concluded that Syrian patients do not apply to the hospital unless an advanced health problem occurs. As a finding that supports this point of view; When the rates of inpatients among the admissions are examined, it can be shown that the rate of hospitalization among the general patient admissions, which is $3.43 \%$, is $13.09 \%$ for Syrian patients. In a study conducted by Yurtseven, Özcan \& Saz (2015) on pediatric patients in the province of Izmir, it was shown that Syrian children were hospitalized more than Turkish children (Yurtseven et al., 2015).

In OECD averages, the number of physicians per 1,000 population is 3.59 , the number of nurses is 10.58 and the number of dentists is 0.74 . these percentages were in Turkey; it emerges as 1.88, 2.34 and 0.38 (OECD, 2020). It has been stated that there is a two-fold difference in favor of EU countries in terms of the number of physicians per thousand people, and a four-fold difference in terms of the number of nurses (Köksal, Turfaner, Sipahioğlu, Yurtsever \& Vehid 2016). According to these results, the basic elements of the health workforce can be considered in terms of professions shows that in a disadvantaged situation in Turkey. Similarly, in a study by Balçık and Nangır (2016), it was stated that this situation negatively affected the workload of these professions (Balçık \& Nangır, 2016). Same way; hospital beds, MRI and CT equipment in terms of numbers it is seen that the considerable disadvantage of Turkey. According to the OECD average, the number of hospital beds per 1000 population is 4.50 , the number of MRI device per million population 16.70 and the number of MRI device per million population 26.60. These rates respectively in Turkey; 2.90, 11.20 and 14.90 (OECD, 2020).

According to OECD countries and European countries, in Turkey, with more limited human resources to provide health services has the potential to affect the local population's access to health services. Taştan, Haklı \& Osmanoğlu (2017), in a study conducted on 400 patients in Ankara, the rate of those who said "With the arrival of Syrians, it became difficult to access health services" was found to be 45\% (Taştan et al., 2017). In a study conducted by Hiçdurmaz \& Yüksel (2020) on the access of irregular migrants living in Europe to health services, it was stated that these people have significant problems in accessing health services. Moreover, it has been stated that these countries do not consider access to health services within the framework of human rights and are considered as a policy area limited by national interests (Hiçdurmaz \& Yüksel, 2020).

The share allocated to healthcare services worldwide and barriers to access to healthcare services are increasing (Schneider \& Devitt, 2018). In this period when many countries experience various problems in terms of the provision of health services, Turkey offers its health infrastructure and facilities to the service of citizens of different countries as well as its own citizens (Sevim, 2019). Despite human resources and technological opportunities emerging in disadvantaged situation in terms of evaluation, can be served without interruption of health services in Turkey can be considered as a success of the health care system. However, it can be stated that it would be appropriate for the Ministry of Health to increase its human resource power by recruiting new physicians and nurses in order to eliminate the health human resource deficit employed throughout the country. Turkey, despite all these limitations, the possibilities to have offers to its people and Syrian refugees. 


\section{Syrian patients' impacts on the healthcare system}

Suriyeli hastaların sağlık sistemi üzerindeki etkileri

\section{Conclusion and Suggestions}

The share of healthcare services from national economies and barriers to accessing healthcare services are increasing globally. In this period, Turkey has resources that are shared with the Syrians refugees. This sharing, in terms of provision of health services is to bring Turkey's health system is on the significant potential side effects.

Although irregular migration is basically not a desired condition, it is important to support those in need. Health, as one of the most fundamental human rights, can also be considered in this context. In addition, considering the social nature of health services, the state should at least deliver primary healthcare services to all of the people who make up its society. Turkey, which have limited resources, as well as their own citizens, was presented to the use of Syrian refugees. As a result of this sharing, it is inconceivable that the health system of a country, which currently ranks low in terms of health human resources, hospital beds per capita, MRI and CT devices in the evaluation made among OECD countries, would not be affected by this sharing.

It is very important to provide health services to 1.4 million Syrian patients annually. The fact that Syrian immigrants constitute $1.43 \%$ of the general applications causes very small increases in the number of operations per surgeon and patient per clinician. In addition, the use of outpatient services instead of emergency service admissions should be encouraged in order for the health system to function properly. According to these results; Turkey offers health services to substantial amount of Syrians patients. Turkey is trying to cope with the additional patient load, which may be a problem for many countries. However, it has been concluded that this situation does not have a significant negative effect on the health system in terms of service delivery in Istanbul.

In future research, the reasons for the admission of Syrian migrant patients to the hospital can be examined in order to comprehensively evaluate the impact on inpatient treatment services.

Ethics Committee Approval: Ethical approval was obtained with the decision of the Bandırma Onyedi Eylül University Health Sciences Non-Interventional Researches Ethics Committee, dated 03.07.2020 and numbered 2020.29.

Conflict of Interest: Not reported.

Funding: None.

Informed Consent: Written consents of the participants were obtained

\section{References}

Aslan, Ş., Sümbül, F. \& Güzel, Ş. (2018). Mültecilerin Kilis sağlık hizmetleri üzerindeki etkisi. Journal of Healthcare Management and Leadership, 1, 48-58. https://doi.org/10.35345/johmal.518977.

Gürbüz, S. \& Duğan, Ö. (2017). Sığınmacılarda sağlık iletişimi: Suriyeli öğretmenler üzerine bir çalışma. Akademik Bakış Dergisi, 64, 479-490.

Hiçdurmaz, Z. \& Yüksel, H. (2020). Sağlık hakkı perspektifinde Avrupa'da yaşayan düzensiz göçmenlerin sağlık hizmetlerine erişimi. Gaziantep Üniversitesi Sosyal Bilimler Dergisi, 19(1), 37-60. https://dergipark.org.tr/tr/pub/jss/issue/52101/627312.

Hopfe, M., Prodinger, B., Bickenbach, J. E. \& Stucki, G. (2018). Optimizing health system response to patient's needs: an argument for the importance of functioning information. Disability and Rehabilitation, 40(19), 2325-2330. https://doi.org/10.1080/09638288.2017.1334234

İlhan, M. N., Gözlü, M., Atasever, M., Dündar, M. A., Büyükgök, D. \& Barkan, O. B. (2016). Göç ve Halk Sağlığı. Ankara: Susam Yayınları.

Korkmaz, A. (2014). The problems caused to the health and nursing services by the asylum seeker. Journal of Health and Nursing Management, 1(1), 37-42. https://doi.org/10.5222/shyd.2014.037.

Korkmaz, A. (2016). Refugee and asylum seekers' health problems: the nursing approach. Middle East Journal of Refugee Studies, 1(2), 75-89. https://doi.org/10.12738/mejrs.2016.1.2.0002.

Köksal, S., Turfaner, S., Sipahioğlu, K., Yurtsever, E. Y. \& Vehid, S. V. (2016). Comparison of Turkey and European countries according to basic health indicators. Turkish Journal of Family Medicine and Primary Care, 10(4), 205. https://doi.org/10.21763/tjfmpc.271087. 


\section{Syrian patients' impacts on the healthcare system}

Suriyeli hastaların sağılı sistemi üzerindeki etkileri

Ministry of Health. (2012). Turkey Health Transformation Program Evaluation Report (2003-2011). https://sbu.saglik.gov.tr/Ekutuphane/Yayin/452 Date of access: 10.03.2020.

Ministry of Health. (2021). Sihhat Projesi. https://www.saglik.gov.tr/TR,79078/sihhat-2-projesi-kapsaminda-psikolog-ve-sosyal-calismaciistihdam-edilecektir.html Date of access: 20.06.2021.

Ministry of Interior. (2019). Syrians Under Our Temporary Protection. Directorate General of Migration Management. https://www.goc.gov.tr/gecici-korumamiz-altindaki-suriyeliler, Date of access: 18.09.2020.

OECD. (2020). Health Statistics. https://www.oecd.org/health/health-statistics.htm Date of access: 03.08.2020.

Önal, A. \& Keklik, B. (2016). Mülteci ve sığınmacıların sağlık hizmetlerine erişimde yaşadığı sorunlar: Isparta ilinde bir uygulama. Süleyman Demirel Üniversitesi Vizyoner Dergisi, 7(15), 132-148. https://doi.org/10.21076/vizyoner.252112.

Önder, N. (2019). Analysis of health policies for temporary protected Syrians in Turkey. Journal of migration studies, 5(1), 110-165. https://dergipark.org.tr/tr/pub/gad/issue/48924/624009.

Schneider, S. M. \& Devitt, C. (2018). Accessing healthcare in times of economic growth and economic downturn: Evidence from Ireland. Journal of European Social Policy, 28(4), 357-369. https://doi.org/10.1177/0958928717739240.

Sevim, E. (2019). Medikal turizm ve stratejik analiz. Ankara, Türkiye: Nobel Yayıncılık.

Taştan, C., Haklı, S. Z. \& Osmanoğlu, E. (2017). Threat perception towards syrian refugees; prejudices and facts. Police Academy Publications.

Turkey Statistics Institute [TurkStat], (2020). Adrese Dayalı Nüfus Kayıt Sistemi Sonuçları, 2020. https://data.tuik.gov.tr/Bulten/Index?p=Adrese-Dayal\%C4\%B1-N\%C3\%BCfus-Kay\%C4\%B1t-Sistemi-Sonu\%C3\%A7lar\%C4\%B1-202037210\&dil=1 Date of access: 21.06 .2021 .

Tuzcu, A. \& Ilgaz, A. (2015). Effects of migration on mental health of women. Psikiyatride Guncel Yaklasimlar - Current Approaches in Psychiatry, 7(1), 56-67. https://doi.org/10.5455/cap.20140503020915.

Uğurluoğlu, Ö. \& Çelik, Y. (2005). Health systems performance measurement, its importance and World Health Organization approach. Hacettepe Journal of Health Administration, 8(1), 3-29.

United Nations [UN], (2019). World Population Prospects 2019, https://population.un.org/wpp/ Date of access: 24.11.2021.

Yurtseven, A., Özcan, G. \& Saz, U. (2015). Comparison of between Syrian patients and Turkish patients who admitted to the pediatric emergency department: Experince of Ege University. Turkish Journal of Pediatric Emergency and Intensive Care Medicine 2(3), $133-136$. https://doi.org/10.5505/cayb.2015.02986. 